\title{
Pengaruh Motivasi Dan Kemampuan Kerja Terhadap Kinerja Karyawan Perusahaan Daerah Bank Perkreditan Rakyat Kabupaten Sukabumi
}

\author{
Suhartini \\ Fakultas Ekonomi dan Bisnis,Universitas Serang Raya \\ Suhartini@unpas.ac.id
}

\begin{abstract}
ABSTRAK
Penelitian ini bertujuan untuk mengetahui seberapa besar pengaruh motivasi dan kemampuan kerja terhadap kinerja karyawan Perusahaan Daerah Bank Perkreditan Rakyat Kabupaten Sukabumi,variabel bebas manakah apakah motivasi atau kemampuan kerja yang lebih berpengaruh terhadap variabel terikat kinerja karyawan Perusahaan Daerah Bank Prekreditan Rakyat Kabupaten Sukabumi.Penelitian ini menggunakan metode kuantitatif dan analisis menggunakan regresi linier berganda dengan bantuan software SPSS versi 20.0 dengan melibatkan 30 orang karyawan Perusahaan Daerah Bank Perkreditan Rakyat sukabumi sebagai responden.Berdasarkan Hasil penelitian menunjukkan bahwa secara parsial variabel motivasi berpengaruh positif terhadap kinerja karyawan sebesar...\%, secara parsial variabel Kemampuan kerja berpengaruh positif terhadap kinerja sebesar...\% dan secara bersama sama variabel motivasi dan kemampuan kerja berpengaruh positif terhadap kinerja karyawan sebesar..\% terhadap kinerja karyawan PD. BPR kabupaten Sukabumi. Sedangkan sisanya...\% dipengaruhi oleh variabel lain yang tidak dimasukkan dalam penelitian ini.Saran yang dapat diberikan pada perusahaan adalah untuk terus meningkatkan motivasi dan kemampuan kerja agar karyawan semangat dan terampil sehingga perusahaan dapat berkembang dengan baik.
\end{abstract}

Kata Kunci : Motivasi, Kemampuan Kerja, Kinerja Karyawan

\section{ABSTRACT}

This study aims to determine how much influence motivation and work ability onemployee performance of the Regional Bank of Sukabumi Rural Bank, which independent variable does the motivation or work ability have more influence on the dependent variable of employee performance of the Regional Credit Bank of Sukabumi Regency. This study uses quantitative methods and analysis using multiple linearregression with the help of SPSS version 20.0 software involving 100 employees of theRegional Bank of Sukabumi Rural Bank as respondents. Based on the resultsof the study showed that partially motivational variables have a positive effect on employee performance by ... \%, 
partially the work ability variable has a positive effecton performance of ...\% and together with motivation and work ability variables have a positive effect on employee performance by ..\% on the performance of PD employees.BPR in Sukabumi district, while the remaining ...\% is influenced by other variables not included in this study. The advice that can be given to the company is to continuously improve motivation and work ability so that employees are enthusiastic and skilled so that the company can develop well.

Keywords: Motivation, Work Ability, Employee's Performance

\section{PENDAHULUAN}

Latar Belakang Masalah

Seiring dengan waktu dan laju pembangunan di Indonesia yang sangat pesat, semakin banyak perusahaan yang tumbuh dan berkembang, Hal ini tentu akan membuat persaingan dalam dunia bisnis yang tidak bisa dihindarimenimbulkan banyak tantangan dan ancaman dalam usaha mencapai tujuan perusahaan.Untuk menghadapi persaingan tersebut, sumber daya manusia mempunyai peranan yang sangat strategis dan perlu mendapat perhatian yang lebih dalam, karena manusialah yang akhirnya menentukan dan memprediksikan keberhasilan atau kegagalan sehingga kebijakan, strategi, target dan langkah-langkah kegiatan operasional perusahaan harus disiapkan. Keadaan ini menjadikan keadaaan sumber daya manusia sebagai aset yang harus dijaga dan ditingkatkan kinerjanya. Oleh karenanya, perusahaan harus mampu menciptakan kondisi yang dapat mendorong dan memungkinkan karyawan untuk termotivasi dan meningkatkan kemampuan serta keterampilan yang dimiliki secara optimal. Peningkatan kinerja tersebut tercermin dari peningkatan kualitas pelayanan, akurasi data dan ketepatan waktu. Lebih jauh lagi dengan kinerja yang baik, karyawan diharapkan dapat memfungsikan diri sebagaimana harapan organisasi bukan sekedar survive tetapi dapat berkembang optimal secara keseluruhan.

Perusahaan Daerah Bank Perkreditan Rakyat (PD.BPR) Sukabumi adalah suatu badan usaha milik Pemerintah Kabupaten Sukabumi yang sebelumnya bernama Bank Karya Produksi Desa (BKPD), sebuah lembaga keuangan yang dibentuk pada tahun 1968 dengan Surat Keputusan Gubernur Jawa Barat Nomor 79/BV/PEM/SK/68 tanggal 16 Maret 1968. Tujuan dasar dibentuknya lembaga keuangan tersebut saat itu dalam rangka membantu pemerintah untuk meningkatkan produksi hasil pertanian masyarakat pedesaan. Sejalan dengan perkembangannya dan atas tuntutan peraturan pemerintah khususnya bidang perbankan, maka pada tahun 1992 melalui Peraturan Pemerintah Nomor 71 dan Keputusan Menteri Keuangan Nomor 184 s/d 196/KM/17/1998,maka berubahlah nama Bank Karya Produksi Desa (BKPD) tersebut menjadi Bank Perkreditan Rakyat (BPR) dengan badan hukum Perusahan Daerah PD. Secara institusional maupun operasional, Perusahaan Daerah Bank Perkreditan Rakyat (PD. BPR) merupakan lembaga keuangan yang bersifat otonom. Walaupun demikian, karena didirikan dan dimiliki oleh pemerintah daerah serta 
menjadi asset daerah, maka ada hubungan atau hirarki tertentu antara Bank Perkreditan Rakyat (BPR) sebagai unit bisnis dengan Pemerintah daerah. Dalam pengertian lain, dapat dikatakan bahwa keberadaan Perusahaan Daerah Bank Perkreditan Rakyat(PD BPR) ini tidak dapat dipisahkan dan merupakan satu kesatuan dalam sistem pemerintahan Kabupaten Sukabumi khususnya dalam mengemban misinya menunjang program-program pemerintah daerah dalam mengimplementasikan kebijakan-kebijakan pembangunannya terutama dibidang perekonomian.

Perkembangan Perusahaan Daerah Bank Perkreditan Rakyat (PD BPR) saat ini tersebar di 21 Kecamatan dalam wilayah Kabupaten Sukabumi dengan 27 kantor cabang dan kantor cabang pembantu. Adapun bentuk pelayanannya meliputi simpanan; berbentuk deposito dan tabungan yaitu; Sibarokah (simpanan barokah), Siwajar (simpanan wajib belajar), Tahara (tabungan hari raya), Sibangkit (simpanan angsuran kredit) dan Taska (tabungan anak sekolah), Tapak (tabungan pajak kendaraan). Sedangkan disisi pelayanan kredit yaitu kredit Umum, kredit investasi, kredit UKM dan kredit kontruksi.Baik simpanan maupun pelayanan kredit dan asset yang dimiliki menunjukkan kecenderungan adanya peningkatan yang cukup signifikan, Demikian Bila dilihat dari sisi kualitas karyawan salahsatu indikatornya pendidikan,pada saat ini Karyawan PD. BPR Sukabumi didominasi berlatar pendidikan sarjana (S1) sebesar 59,6\%. Lulusan SLTA 27,3\%, sedangkan sisanya 13,1\% lulusan D3, dan SLTP.Sedangkan status tatus kepegawaian pada Perusahaan Daerah BPR. Sukabumi 88,3\% merupakan pegawai tetap, dan $11,7 \%$ adalah pegawai kontrak.

Berdasarkan hal diatas penulis tergerak untuk membuktikan seberapa besar pengaruh motivasi terhadap kinerja pegawai, membuktikan seberapa besar pengaruh kemampuan kerja terhadap kinerja pegawai dan membuktikan seberapa besar pengaruh motivasi dan kemampuan kerja terhadap kinerja pegawai di PD. BPR.Kabupaten Sukabumi.

\section{LANDASAN TEORI DAN PENGEMBANGAN HIPOTESIS}

\section{Motivasi}

Motivasi merupakan dorongan yang dimiliki oleh manusia untuk memenuhi keinginan sehingga melakukan kegiatan- kegiatan tertentu. Dalam dunia pekerjaan, Motivasi mempersoalkan bagaimana caranya mendorong gairah kerja bawahan, agar mereka mau bekerja keras dengan memberikan semua kemampuan dan keterampilannya untuk mewujudkan tujuan perusahaan. Menurut Rivai (2010:837), motivasi adalah "serangkaian sikap dan nilai-nilai yang mempengaruhi individu untuk mencapai hal yang spesifik sesuai dengan tujuan individu". Sedangkan Menurut Robbins dan Judge (2008:222) mendefinisikan motivasi (motivation) sebagai proses yang menjelaskan intensitas, arah, dan ketekunan seorang individu untuk mencapai tujuannya. Kemudian Fillmore dalam Mangkunegara (2005:93) mendefinisikan bahwa "Motivation as an energizing condition of the organism that serves to direct that organism toward the goal of 
a certain class" (Motivasi sebagai suatu kondisi yang menggerakkan manusia ke arah suatu tujuan tertentu). Demikian pula menurut Harold Koontz (Hasibuan 2003:95) "Motivation refers to the drive and effort to satisfy a want or goal.Motivasi mengacu pada dorongan dan usaha untuk memuaskan kebutuhan atau suatu tujuan.

Menurut Wayne F Casio (Hasibuan 2003:95) "Motivations is force that result from and individuals desire to satisfy there needs (e.g. hunger, thirst, social approval). Motivasi adalah suatu kekuatan yang dihasilkan dari keinginan seseorang untuk memuaskan kebutuhannya (misalnya; rasa lapar, haus, dan bermasyarakat). Sedangkan Stephen P. Robbins (Hasibuan 2003:95), We 'll define motivation as the willingness to exert high levels of effort toward organizational goals, conditional by efforts ability and satisfy some individual need. Kita akan mendefinisikan motivasi sebagai suatu kerelaan untuk berusaha seoptimal mungkin dalam pencapaian tujuan organisasi yang dipengaruhi oleh kemampuan usaha untuk memuaskan beberapa kebutuhan individu. Merle J.Moskowits (Hasibua 2003:95), "Motivation is usually defined the initiative and direction of behavior and the study of motivation is the effect the study of course of behavior.Motivasi secara umum dapat didefinisikan sebagai inisiatif dan pengarahan tingkah laku dan pelajaran motivasi sebenarnya merupakan pelajaran tingkah laku".

Berdasarkan kutipan diatas dapat dikemukakan bahwa motivasi merupakan suatu kebutuhan yang harus dipenuhi dengan melakukan inisiatif, kerelaan dalam melakukannya dan berusaha memuaskan kebutuhan tersebut dengan cara-cara tertentu.

\section{Kemampuan Kerja}

Kemampuan pegawai menurut Little field dan Peterson (Hasibuan,1993;51) mengemukakan tiga (3) persyaratan yang harus dimiliki oleh pegawai / karyawan yaitu :

\section{Tecnikal Skills}

Keterampilan yang harus dimilki untuk dapat menggerakan (memakai) alat -alat teknis dan benda-benda mati lainnya (mesin-mesin), bahan baku, prosedur kerja (berhubungan dengan kegiatan menghadapi unsur bukan manusia)

\section{Human Skills}

Keterampilan yang dimiliki dalam bidang kemanusiaan untuk menggerakaan manusia, (misalnya untuk bergaul yakni berinteraksi saling berhubungan,saling mengerti, menyelami keinginan atau perasaan atau motif-motif bertindak, atau norma-norma yang berkepribadian),memahami sifat dan karakter manusia.Sifat dan kepribadian sesorang terbentuk oleh pembawaan dan lingkungan sosialnya.

\section{Conceptual Skills}

Keterampilan yang dimiliki seseorang untuk menggerakan perusahaan / organisasi, melihat masa depan perusahaan, keterampilan menyusun rencana, menentukan dan menyusun organisasi yang baik, menempatkan orang-orang pada jabatan yang tepat, 
membuat suatu keputusan yang tepat, membuat suatu keputusan yang tepat bagi perusahaan secara keseluruhan.

\section{Kinerja Karyawan}

Kinerja merupakan suatu kondisi yang harus diketahui dan diinformasikan kepada pihak-pihak tertentu untuk mengetahui tingkat pencapaian hasil suatu instansi dihubungkan dengan visi yang diemban suatu organisasi serta mengetahui dampak positif dan negative dari suatu kebijakan operasional yang diambil. Hersey dan Blanchar dalam Giri(2005:1) mengungkapkan bahwa kinerja merupakan fungsi motivasi dan kemampuan. Kemampuan seseorang merupakan ukuran pertama dalam meningkatkan yang ditunjukkan oleh hasil kerjanya. Dengan kata lain Kinerja adalah hasil kerja secara kualitas dan kuantitas yang dicapai oleh seorang pegawai dalam melaksanakan tugasnya sesuai dengan tanggung jawab yang diberikan kepadanya. (Mangkunegara,2016:67). Sedangkan Khasmir (2015: 183) Kinerja hasil kerja dan perilaku perilaku kerja yang telah dicapai dalam menyelsaikan tugas-tugas dan tanggungjawab yang diberikan dalam suatu periode tertertu. Selanjutnya menurut Anwar Prabu (2004:67), kinerja dapat diukur melalui dua dimensi yaitu kualitas karyawan dan kuantitas karyawan.

Menurut Armstrong dan Baron (Wibowo,2014:7) Kinerja merupakan hasil pekerjaan yang mempunyai hubungan kuat dengan tujuan strategis organisasi, kepuasan konsumen, dan memberikan konstribusi pada ekonomi.

Menurut Robert L. Mathis (2014 : 378) beberapa indikator kinerja adalah :

1. Kuantitas dari hasil

Kuantitas merupakan jumlah yang dihasilkan dinyatakan dalam istilah seperti jumlah unit, jumlah siklus aktivitas diselesaikan.Kuantitas yang diukur dari persepsi pegawai terhadap jumlah aktivitas yang ditugaskan beserta hasilnya.

2. Kualitas dari hasil

Kualitas adalah ketaatan dalam prosedur, disiplin, dedikasi. Tingkat dimana hasil aktivitas yang dikehendaki sempurna dalam arti menyesuaikan beberapa cara ideal dari penampilan aktivitas, maupun memenuhi tujuan-tujuan yang diharapkan dari suatu aktivitas. Kualitas kerja diukur dari persepsi pegawai terhadap kualitas pekerjaan yang dihasilkan serta kesempurnaan tugas terhadap keterampilan dan kemampuan pegawai.

3. Ketepatan Waktu dari hasil

Ketepatan waktu adalah Karyawan yang dapat menyelesaikan suatu target tepat waktu juga dikatakan memiliki kinerja yang baik. Jika karyawan tidak dapat menyelesaikan tepat waktu maka akan merugikan suatu perusahaan. 


\section{Kehadiran}

Kehadiran adalah keyakinan akan masuk kerja setiap hari dan sesuai dengan jam kerja.

5. Kemampuan bekerjasama

Kemampuan seorang tenaga kerja untuk bekerja bersama dengan orang lain dalam menyelesaikan suatu tugas dan pekerjaan yang telah ditetapkan sehingga mencapai daya guna dan hasil guna yang sebesar-besarnya. Menurut Davis (Anwar, 2004:67) Faktor yang mempengaruhi pencapaian kinerja adalah kemampuan (ability) dan motivasi (motivation) atau dengan rumus:

Human Performance $=$ Ability + Motivation

Motivation $=$ Attitude + Situation

Ability $=$ Knowledge + Skiil

serta waktu.seseorang dalam melaksanakan tugas-tugas yang dibebankan kepadanya didasarkan atas kecakapan, pengalaman, kesungguhan

\section{METODE PENELITIAN}

Metode dalam penelitian ini menggunakan metode kuantitatif.yaitu dengan melakukan pengujian hipotesis dengan menggunakan sampel yang mencerminkan populasi dengan menggunkan metode pengumpulan data.Responden dalam penelitian ini adalah sebanyak 30 pegawai. Sampel dalam penelitian ini menggunakan teknik simple random sampling random yaitu teknik pengambilan sample dimana setiap elemen atau anggota populasi mempunyai kesempatan yang sama untuk terpilih menjadi sampel.

Pengukuran Variabel

Dalam pengukuran ini, menggunakan skala pengukuran yang dinamakan skala pengukuran skala Likert. Sugiono menjelaskan,skala Likert digunakan untuk mengukur sikap,pendapat dan presepsi seseorang atau sekelompok orang tentang kejadian atau gejala sosial. Dalam penelitian gejala sosial ini telah ditetapkan secara spesifik oleh peneliti, yang selanjutnya disebut sebagai variable penelitian.

Teknik Analisis Data

1. Uji Validitas

Uji Validitas digunakan untuk mengukur sah atau tidaknya suatu kuesioner. Suatu kuesioner dikatakan valid jika pertanyaan pada kuesioner mampu mengungkapkan sesuatu yang akan diukur oleh kuesioner tersebut. Untuk mengukur validitas dapat dilakukan dengan melakukan korelasi antar skor butir pertanyaan dengan total skor konstruk atau variable. Hasil penelitian yang valid bila terdapat kesamaan antara data yang terkumpul dengan data yang sesungguhnya terjadi pada objek yang diteliti. 


\section{- Uji Reliabilitas}

Uji Reliabilitas adalah serangkaian pengukuran atau serangkaian alat ukur yang memiliki konstitensi bila pengukuran yang dilakukan dengan alat ukur itu dilakukan secara berulang. Suatu kuesioner dikatakan reliabel atau handal jika jawaban seseorang terhadap pernyataan adalah konsisten atau stabil dari waktu ke waktu.

c. Uji Normalitas Data

Menurut Ghozali (2013:160) uji normalitas bertujuan untuk menguji apakah dalam model regresi, variable penganggu atau residual memiliki distribusi normal. Seperti diketahui bahwa uji t dan uji f mengasumsikan bahwa nilai residual mengikuti distribusi normal.

d. Analisis Regresi Berganda

Untuk mengukur pengaruh antara motivasi dan kemampuan pegawai dengan kinerja pegawai dengan mengunakan metode analisis regresi berganda. Rumus yang dipergunakan adalah :

$$
Y=a+b_{1} x_{1}+b_{2} x_{2}
$$

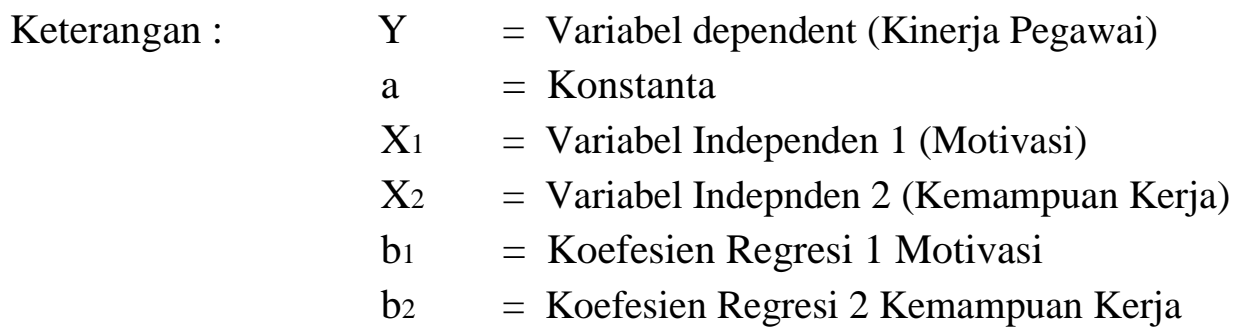

C. Analisis Koefesien Determinasi

Menurut Imam Ghozali (2005 : 141), koefesien determinasi menunjukan suaru proposi dari varian yang dapat diterangi oleh persamaan regresi terhadap variable total. Nilai koefesien korelasi lebih besar dari 0,5 menunjukan variable bebas dapat menjelaskan variable terikat dengan baik atau kuat (signifikan), sama dengan 0,5 atau kurang dari 0,5 relatif kurang baik (Suharyadi, 2004 : 217). Rumus yangdigunakan sebagai berikut:

$$
\mathrm{Kd}=\mathbf{R}^{2} \times 100 \%
$$

Keterangan :

$\mathrm{Kd}=$ Koefesien Determinasi

$\mathrm{R}=$ Koefesien Korelasi

\section{- Pengujian Hipotesis}

Untuk memastikan hasil yang diperoleh melalui pertimbangan korelasi, maka harus dilakukan pengujian hipotesis untuk membuktikan hasil yang telah diperoleh tersebut. 
- $\quad$ Pengujian Hipotesis Secara Parsial (Uji T)

Kriteria pengambilan keputusan digunakan pengujian dengan menggunakan statistik uji t yaitu :

$$
t=\frac{b-\beta}{s_{b}}
$$

Dimana :

$\mathrm{b}=$ Koefesien regresi sample

$\beta=$ Koefesien regresi populasi

$s_{b}=$ Galat baku koefesien regresi

Berikut formulasi $\mathrm{H} 0$ dan $\mathrm{H} 1$ :

1. $\mathrm{X} 1$

Ho $: \beta_{1}=0$, artinya tidak ada pengaruh yang signifikan dari motivasi terhadap kinerja pegawai PD.BPR. Kabupaten Sukabumi.

$\mathrm{H} 1:{ }_{1} \neq 0$,artinya terdapat pengaruh yang signifikan dari motivasi kerja terhadap kinerja pegawai pada PD. BPR. Kabupaten Sukabumi.

2. $\mathrm{X} 2$

Ho $: \beta_{2}=0$, artinya tidak ada pengaruh yang signifikan dari kemampuan kerja pegawai terhadap kinerja pegawai pada PD. BPR. Kabupaten Sukabumi

H1 $: \beta_{2} \neq 0$,artinya terdapat pengaruh yang signifikan dari Kemampuan kerja terhadap kinerja pegawai pada PD. BPR. Kabupaten Sukabumi.

Setelah memperoleh nilai hasil perhitungan uji t diatas, maka

Langkah selanjutnya yang akan dilakukan adlah menguji nilai tersebut dengan menggunakan uji hipotesis pada t.adapun kriteria penerimaan hipotesis adalah sebagai berikut :

a. Jika $\mathrm{t}$ hitung $\leq \mathrm{t}$ tabledf $=\mathrm{n}-2$ maka $\mathrm{H} 0$ diterima dan $\mathrm{H} 1$ ditolak.

b. Jika t hitung $\geq \mathrm{t}$ tabledf $=\mathrm{n}-2$ maka $\mathrm{H} 0$ ditolak a dan $\mathrm{H} 1$ diterima.

B. Pengujian Hipotesis Secara Simultan (Uji F)

Menentukan Nilai $F$ hitung dengan rumus :

$$
F_{\text {hitung }}=\frac{R^{2} / k}{\left(1-R^{2}\right) /(n-k-1)}
$$


Dimana :

$$
\begin{array}{lll}
\mathrm{R}^{2} & =\text { Koefesien regresi berganda } \\
\mathrm{k} & = & \text { Jumlah } \\
& \text { independent } \\
\mathrm{n} & =\text { Junlah anggota sampel } \\
\mathrm{F} & \text { = Nilai F yang dihitung }
\end{array}
$$

Menentukan nilai taraf signifikan untuk penelitian ini penulis mengambil tingkat keyakinan sebesar 95\% sehingga tingkat kesalahan $(\alpha)$ sebesar 5\% atau $\alpha=0,05$. Untuk uji ini diperlukan mengetahui derajat kebebasan (dk), dan untuk mencari $\mathrm{dk}$ pembilang digunakan nilai ke-1, yaitu variable dikurangi 1. Untuk dk penyebut digunakan nilai n-k, yaitu jumlah sampel dikurangi jumlah variable.

Adapun kriteria penerimaan hipotesis adalah sebagai berikut :

1. Jika Fhitung $>$ Ftabledf $=\mathrm{n}-3$ maka H0 ditolak dan H1 diterima. Artinya terdapat pengaruh yang signifikan dari variabel X1 dan variabel X2 terhadap variabel $\mathrm{Y}$.

2. Jika Fhitung $<$ Ftabledf $=$ n-3 maka H1 ditolak dan $\mathrm{H} 0$ diterima. Artinya tidak terdapat pengaruh yang signifikan dari variabel X1 dan variabel X2 terhadap variabel Y.

\section{HASIL ANALISIS DAN PEMBAHASAN}

Teknik Analisis Data

1. Uji Validitas

1.1.Uji Validitas Motivasi Kerja

Tabel 1.1

Hasil Uji Validitas Variabel Motivasi Kerja

\begin{tabular}{|c|c|c|c|}
\hline Pertanyaan & Corrected Item-Total Correlation & r tabel & Kesimpulan \\
\hline X1_1 & 0,869 & 0,273 & Valid \\
\hline X1_2 & 0,805 & 0,273 & Valid \\
\hline X1_3 & 0,776 & 0,273 & Valid \\
\hline X1_4 & 0,705 & 0,273 & Valid \\
\hline X1_5 & 0,878 & 0,273 & Valid \\
\hline
\end{tabular}

Sumber : Data diolah dengan SPSS 20 
1.2.Uji Validitas Kemampuan Kerja

Tabel 1.2

Hasil Uji Validitas Kemampuan Kerja

\begin{tabular}{|c|c|c|c|}
\hline Pertanyaan & Corrected Item-Total Correlation & $\mathrm{r}$ tabel & Kesimpulan \\
\hline $\mathrm{X} 2 \_1$ & 0,901 & 0,273 & Valid \\
\hline $\mathrm{X} 2 \_2$ & 0,847 & 0,273 & Valid \\
\hline $\mathrm{X} 2 \_3$ & 0,882 & 0,273 & Valid \\
\hline $\mathrm{X} 2 \_4$ & 0,801 & 0,273 & Valid \\
\hline $\mathrm{X} 2 \_5$ & 0,915 & 0,273 & Valid \\
\hline
\end{tabular}

Sumber : data diolah dengan SPSS 20

1.3.Uji Validitas Kinerja Karyawan

Tabel 1.3

Hasil Uji Validitas Kinerja Karyawan

\begin{tabular}{|c|c|c|c|}
\hline $\begin{array}{r}\text { Pert } \\
\text { anyaan }\end{array}$ & $\begin{array}{c}\text { Corrected Item-Total } \\
\text { Correlation }\end{array}$ & $\begin{array}{c}\text { Kesi } \\
\text { tabel }\end{array}$ & \begin{tabular}{c} 
mpulan \\
\hline Y_1
\end{tabular} \\
\hline Y_2 & 0,759 & 0,273 & Valid \\
\hline Y_3 & 0,813 & 0,273 & Valid \\
\hline Y_4 & 0,871 & 0,273 & Valid \\
\hline Y_5 & 0,761 & 0,273 & Valid \\
\hline
\end{tabular}

Sumber : Data diolah dengan SPSS 20

2. Uji Reliabilitas

2.1 Uji Reliabilitas Motivasi Kerja 
Tabel 1.4

\section{Hasil Uji Reliabilitas Motivasi Kerja}

Reliability Statistics

\begin{tabular}{|r|r|}
\hline Cronbach's Alpha & N of Items \\
\hline, 864 & \\
\hline
\end{tabular}

Sumber : data diolah dengan SPSS 20

Berdasarkan kategori diatas variabel motivasi kerja terdiri dari 5 pertanyaan yang mewakili dengan nilai cronbach's alpha sebesar 0,864 karena nilai $0,864>0,80$ maka dapat dikatakan bahwa data diatas bersifat reliable dengan reliabilitas sangat tinggi

\subsection{Uji Reliabilitas Kemampuan Kerja}

Tabel 1.5

\section{Hasil Uji ReliabilitasKemampuan Kerja}

\section{Reliability Statistics}

\begin{tabular}{|r|r|}
\hline Cronbach's Alpha & N of Items \\
\hline, 918 & \\
\hline
\end{tabular}

Sumber : Data diolah dengan SPSS 20

Berdasarkan kategori diatas variabel kemampuan kerja terdiri dari 5 pertanyaan yang mewakili dengan nilai cronbach's alpha sebesar 0,918 karena nilai 0,918 > 0,80 maka dapat dikatakan bahwa data diatas bersifat reliable dengan reliabilitas sangat tinggi.

2.3 Uji Reliabilitas Kinerja Karyawan

Tabel 1.6

Hasil Uji Reabilitas Kinerja Karyawan

Reliability Statistics

\begin{tabular}{|r|r|}
\hline $\begin{array}{c}\text { Cronbach's } \\
\text { Alpha }\end{array}$ & N of Items \\
\hline, 851 & 5 \\
\hline
\end{tabular}

Sumber : Data diolah dengan SPSS 20 
Berdasarkan kategori diatas variabel Kinerja Karyawan terdiri dari 5 pertanyaan yang mewakili dengan nilai cronbach's alpha sebesar 0,851 karena nilai $0,851>$ 0,80 maka dapat dikatakan bahwa data diatas bersifat reliable dengan reliabilitas sangat tinggi

3. Uji Asumsi Klasik

1. Uji Normalitas

Tabel 1.7

Hasil Uji Normalitas

One-Sample Kolmogorov-Smirnov Test

\begin{tabular}{|ll|r|}
\hline & & $\begin{array}{r}\text { Unstandardiz } \\
\text { ed Residual }\end{array}$ \\
\hline $\mathrm{N}$ & Mean & $0 \mathrm{E}-7$ \\
Normal Parameters & Std. & \\
& Deviation & 3,10732274 \\
Most Extreme & Absolute &, 088 \\
Differences & Positive &, 088 \\
& Negative &,- 079 \\
Kolmogorov-Smirnov Z &, 625 \\
Asymp. Sig. (2-tailed) & &, 830 \\
\hline
\end{tabular}

a. Test distribution is Normal.

b. Calculated from data.

Sumber : Data diolah dengan SPSS 20

Berdasarkan hasil uji normalitas diketahui nilai signifikansi 0,830 >0,05. Maka dapat disimpulkan bahwa nilai residual berdistribusi normalsehingga dapat digunakan untuk penelitian selanjutnya. 


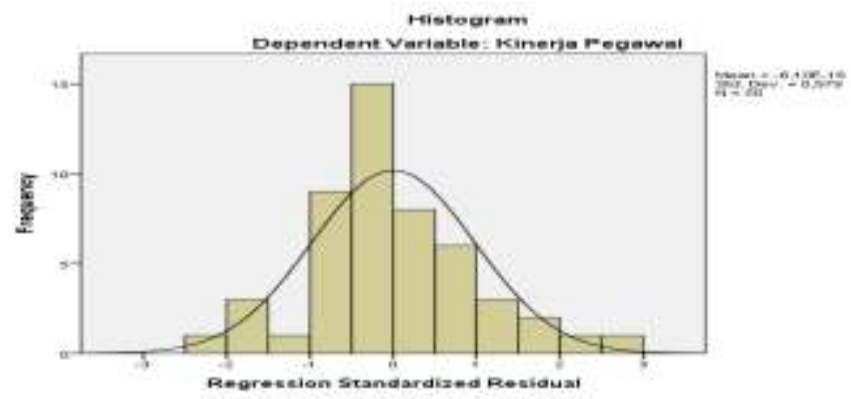

Gambar 1.1 Histogram Uji Normalitas

Sumber : diolah dengan SPSS 20

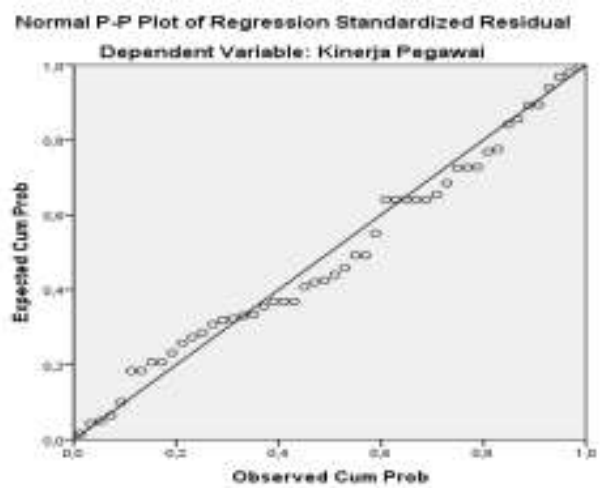

Gambar 1.2Normal P-Plot Uji Normalitas

Sumber : diolah dengan SPSS 20

2. Uji Multikolinearitas

Tabel 1.8

Hasil Uji Multikolinearitas

Coefficients $^{\text {a }}$

\begin{tabular}{|c|c|c|c|c|c|c|c|}
\hline \multirow[t]{2}{*}{ Model } & \multicolumn{2}{|c|}{$\begin{array}{c}\text { Unstandardized } \\
\text { Coefficients }\end{array}$} & \multirow{2}{*}{$\begin{array}{c}\text { Standardize } \\
\mathrm{d} \\
\text { Coefficient } \\
\mathrm{s} \\
\text { Beta }\end{array}$} & \multirow[t]{2}{*}{$\overline{\mathrm{T}}$} & \multirow[t]{2}{*}{ Sig. } & \multicolumn{2}{|c|}{$\begin{array}{c}\text { Collinearity } \\
\text { Statistics }\end{array}$} \\
\hline & B & $\begin{array}{l}\text { Std. } \\
\text { Error }\end{array}$ & & & & $\begin{array}{c}\text { Toleranc } \\
\mathrm{e}\end{array}$ & VIF \\
\hline 1 (Constant) & 2,536 & 1,349 & & 1,879 &, 066 & & \\
\hline
\end{tabular}




\begin{tabular}{|c|c|c|c|c|c|c|c|}
\hline Motivasi Kerja & ,379 &, 179 & ,369 & 2,117 & , 040 & ,184 & 5,442 \\
\hline $\begin{array}{l}\text { Kemampuan } \\
\text { Kerja }\end{array}$ & ,474 &, 162 & ,510 & 2,924 & ,005 &, 184 & 5,442 \\
\hline
\end{tabular}

a. Dependent Variable: Kinerja Karyawan

Sumber : Data diolah dengan SPSS 20 (2018)

Berdasarkan tabel di atas menunjukkan bahwa nilai tolerance dari kedua variabel independen berada diatas 0,10 dan VIF kurang dari 10. Dengan demikian dapat disimpulkan bahwa dalam model regresi tersebut tidak terdapat masalah multikolinearitas.

3. Uji Heterokedastisitas

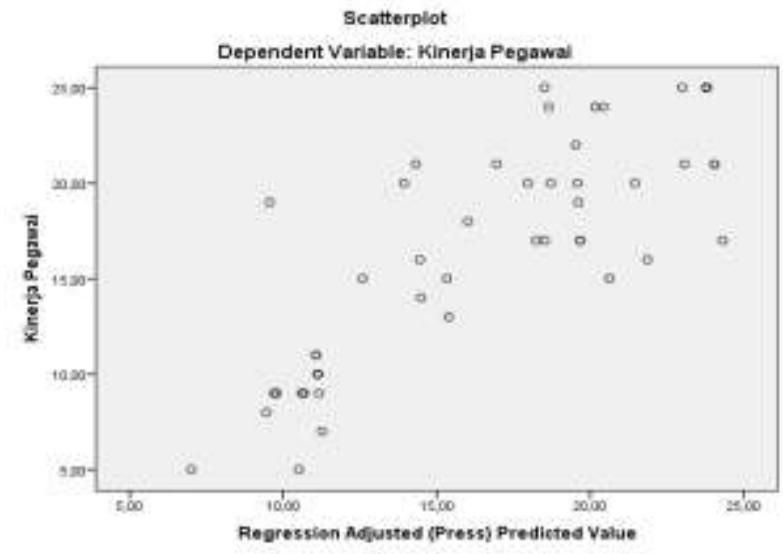

Gambar 1.3 Uji Heterokedastisitas

Berdasarkan gambar di atas Suatu regresi dikatakan terdeteksi heterokedasitasnya apabila diagram pencar residual membentuk pola tertentu. Tampak pada output di atas diagram pencar residual tidak bergelombang, tidak melebar dan tidak menyempit kemudian titik-titik menyebar secara acak serta data tersebar di atas maupun dibawah angka 0 pada sumbu Y. Kesimpulannya, regresi terbebas dari kasus heterokedasitas.

4. Uji Autokorelasi

Tabel 1.9

Hasil Uji Autokorelasi 
Model Summary ${ }^{b}$

\begin{tabular}{|l|r|r|r|r|r|}
\hline Model & \multicolumn{1}{|c|}{$\mathrm{R}$} & R Square & \multicolumn{1}{|c|}{$\begin{array}{c}\text { Adjusted R } \\
\text { Square }\end{array}$} & $\begin{array}{c}\text { Std. Error of } \\
\text { the Estimate }\end{array}$ & $\begin{array}{c}\text { Durbin- } \\
\text { Watson }\end{array}$ \\
\hline 1 &, $859^{\mathrm{a}}$ &, 737 &, 726 & 3,17275 & 1,711 \\
\hline
\end{tabular}

a. Predictors: (Constant), Kemampuan Kerja, Motivasi Kerja

b. Dependent Variable: Kinerja Karyawan

Sumber : Hasil pengolahan data SPSS Statistik versi 20 (2018)

Berdasarkan hasil perhitungan SPSS maka Durbin-Watson yang diperoleh sebesar 1,638 dengan $\alpha=5 \%$ diperoleh batas bawah Durbin-Watson $\left(\mathrm{d}_{\mathrm{L}}\right)=1,4625$ dan batas atas Durbin-Watson $\left(\mathrm{d}_{\mathrm{u}}\right)=1,6283$ dimana $\mathrm{du}<\mathrm{d}<4$-du atau $1,4625<1,711<$ 2,5375 yang berarti tidak ditolak sehingga model regresi tidak terdapat autokorelasi positif maka penelitian ini dapat dilanjutkan dengan uji penelitian selanjutnya.

4. Analisis Regresi Berganda

Tabel 1.10

Hasil Uji Regresi linear berganda

Coefficients $^{\mathrm{a}}$

\begin{tabular}{|l|r|r|r|r|r|}
\hline Model & \multicolumn{2}{|c|}{$\begin{array}{c}\text { Unstandardized } \\
\text { Coefficients }\end{array}$} & $\begin{array}{l}\text { Standardized } \\
\text { Coefficients }\end{array}$ & $\mathrm{t}$ & Sig. \\
\cline { 2 - 4 } & B & Std. Error & Beta & & \\
\hline \multicolumn{1}{c|}{ (Constant) } & 2,536 & 1,349 & & 1,879 &, 066 \\
1 Motivasi Kerja &, 379 &, 179 &, 369 & 2,117 &, 040 \\
$\begin{array}{l}\text { Kemampuan } \\
\text { Kerja }\end{array}$ &, 474 &, 162 &, 510 & 2,924 &, 005 \\
\hline
\end{tabular}

a. Dependent Variable: Kinerja Karyawan

Sumber : Data diolah dengan SPSS 20

$$
\mathrm{Y}=2,536+0,379 \mathrm{X} 1+0,474 \mathrm{X} 2+\mathrm{e}
$$


5. Analisis Koefesien Determinasi

Tabel 1.11

Koefisien Determinasi

Model Summary

\begin{tabular}{|l|r|r|r|}
\hline Model & \multicolumn{1}{|c|}{$\mathrm{R}$} & R Square & \multicolumn{1}{c|}{$\begin{array}{c}\text { Adjusted R } \\
\text { Square }\end{array}$} \\
\hline 1 &, $859^{\mathrm{a}}$ &, 737 &, 726 \\
\hline
\end{tabular}

a. Predictors: (Constant), Kemampuan Kerja,

Motivasi Kerja

b. Dependent Variable: Kinerja Karyawan

Sumber : Data diolah dengan SPSS 20

Berdasarkan data di atas untuk mengetahui besarnya hubungan dari motivasi kerja dan kemampuan kerja secara bersama-sama (simultan) terhadap kinerja karyawan dapat diketahui dari $\mathrm{r}^{2}$ pada tabel model summary yakni sebesar $0,737 \mathrm{x} 100 \%=73,7 \%$. Angka tersebut menunjukkan bahwa motivasi kerja dan kemampuan kerja mampu menjelaskan kinerja karyawan sebesar 0,737 atau $73,7 \%$ dan sisanya sebesar $26,3 \%$ disebabkan oleh faktor yang lain yang tidak diteliti misalnya indikator kinerja karyawan lainnya.

6. Pengujian Hipotesis

A. Pengujian Hipotesis Secara Parsial (Uji T)

Tabel 1.12

Hasil Uji t

Coefficients $^{\mathrm{a}}$

\begin{tabular}{|l|c|c|c|c|c|}
\hline Model & \multicolumn{2}{|c|}{$\begin{array}{c}\text { Unstandardized } \\
\text { Coefficients }\end{array}$} & $\begin{array}{c}\text { Standardized } \\
\text { Coefficients }\end{array}$ & $\mathrm{t}$ & Sig. \\
\cline { 2 - 5 } & $\mathrm{B}$ & Std. Error & Beta & \\
\hline
\end{tabular}




\begin{tabular}{|l|r|r|r|r|r|}
\hline \multicolumn{1}{|c|}{ (Constant) } & 2,536 & 1,349 & & 1,879 &, 066 \\
1 Motivasi Kerja &, 379 &, 179 &, 369 & 2,117 &, 040 \\
$\begin{array}{l}\text { Kemampuan } \\
\text { Kerja }\end{array}$ &, 474 &, 162 &, 510 & 2,924 &, 005 \\
\hline
\end{tabular}

a. Dependent Variable: Kinerja Karyawan

Sumber : Data diolah dengan SPSS 20

\section{Uji Hipotesis Motivasi Kerja}

Dari hasil tabel coefficients di atas diperoleh nilai sig pada Motivasi Kerjaadalah 0,00. Nilai sig ini lebih kecil dari nilai probabilitas 0,05 atau 0,04< 0,05 maka $\mathrm{H}_{0}$ ditolak dan $\mathrm{H}_{1}$ diterima.Nilai uji t pada motivasi kerja didapat nilai $\mathrm{t}_{\text {hitung }}$ adalah2,117 sedangkan $\mathrm{t}_{\text {tabel }}$ dengan tingkat signifikansi 5\% dengan uji dua arah dan derajat kebebasan $(\mathrm{dk})=\mathrm{n}-\mathrm{k}=50-3=47$ adalah 2,01174 dimana $t_{\text {hitung }}>t_{\text {tabel }}(2,117>2,011)$. Berdasarkan hasil tersebut maka $t_{\text {hitung berada di }}$ daerah penolakan $\mathrm{H}_{0}$ atau $\mathrm{H}_{1}$ diterima sehingga dapat disimpulkan bahwa Motivasi Kerja secara parsial memiliki hubungan positif dan signifikan dengan Kinerja Karyawan.

2. Uji Hipotesis Kemampuan Kerja.

Dari hasil tabel coefficients di atas diperoleh nilai sig pada kemampuan kerja adalah 0,005. Nilai sig ini lebih kecil dari nilai probabilitas 0,005 atau 0,005< 0,05 maka $\mathrm{H}_{0}$ ditolak dan $\mathrm{H}_{1}$ diterima. Nilai uji t pada kemampuan kerja didapat nilai $t_{\text {hitung }}$ adalah 2,924 sedangkan $t_{\text {tabel }}$ dengan tingkat signifikansi 5\% dengan uji dua arah dan derajat kebebasan $(\mathrm{dk})=\mathrm{n}-\mathrm{k}=50-3=47$ adalah 2,01174 dimana $t_{\text {hitung }}>\mathrm{t}_{\text {tabel }}(2,924>2,01174)$. Berdasarkan hasil tersebut maka $t_{\text {hitung }}$ berada di daerah penolakan $\mathrm{H}_{0}$ atau $\mathrm{H}_{1}$ diterima sehingga dapat disimpulkan bahwa kemampuan kerja secara parsial memiliki hubungan positif dan signifikan dengan kinerja karyawan.

B. Pengujian Hipotesis Secara Simultan (Uji F)

Tabel 1.13

Hasil Uji F

ANOVA $^{\mathrm{a}}$ 


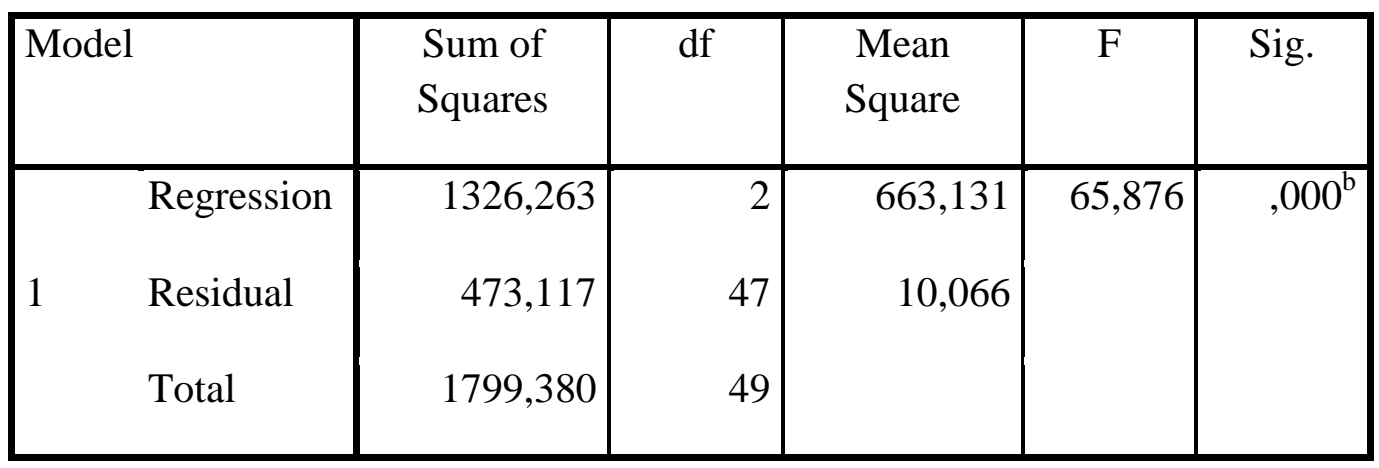

a. Dependent Variable: Kinerja Karyawan

b. Predictors: (Constant), Kemampuan Kerja, Motivasi Kerja

Sumber : Data diolah dengan SPSS 20

Dari tabel hasil uji $\mathrm{F}$ di atas diperoleh nilai sig pada tabel anova adalah 0,000. Nilai sig ini lebih kecil dari nilai probabilitas 0,05 atau $0,000<0,05$ maka $\mathrm{H}_{0}$ ditolak dan $\mathrm{H}_{\mathrm{a}}$ diterima. Kemudian untuk nilai $\mathrm{F}_{\text {hitung }}$ sebesar 65,876 sedangkan $\mathrm{F}$ tabel dengan tingkat signifikansi 5\% diperoleh derajat kebebasan untuk pembilang (df1) adalah k -1 berarti df $1=3-1=2$ dan derajat kebebasan untuk penyebut $(\mathrm{df} 2)=\mathrm{n}-\mathrm{k}$ berarti df $2=50-3=47$. Maka didapat $F_{\text {tabel }}$ dua arah sebesar 3,20. Hasil $F_{\text {hitung }}>F_{\text {tabel }}$ $(65,876>3,20)$. Berdasarkan hasil perhitungan tersebut maka $\mathrm{H}_{\mathrm{a}}$ diterima dan $\mathrm{H}_{0}$ ditolak maka dan dapat disimpulkan bahwa antara motivasi kerja dan kemampuan kerja secara bersama-sama (simultan) memiliki hubungan positif dan signifikan dengan kinerja karyawan.

\section{KESIMPULAN}

1. Terdapat pengaruh poistif dan signifikan variabel Motivasi terhadap variabel Kinerja Karyawan pada Perusahaan Daerah Bank Perkreditan Rakyat Kabupaten Sukabumi. Dalam hal ini didukung bahwa karyawan PD.BPR Sukabumi mempunyai keinginan untuk maju, bekerja dengan team yang kompak, dan karyawan mempunyai karier yang jelas.

2. Terdapat pengaruh positif dan signifikan variabel Kemampuan Kerja terhadap variabel Kinerja Karyawan pada Perusahaan Daerah Bank Perkreditan Rakyat Kabupaten Sukabumi. Dalam hal ini didukung bahwa Karyawan PD. BPR Sukabumi memahami tugas secara jelas dalam pekerjaannya, menanggapi dengan capat apa yang menjadi keinginan nasabah dalam bidang pekerjaanya, sikap ramah dan bersahabat merupakan salah satu pelayanan yang sangat penting

3. Terdapat pengaruh positif dan signifikan secara simultan variabel Motivasi Kerja dan Kemampuan Kerja secara bersama-sama terhadap variabel Kinerja Karyawan pada Perusahaan Daerah Bank Perkreditan Rakyat Kabupaten Sukabumi, sebesar 65.9\%. sedangka sisanya sebesar $34,1 \%$ adalah variabel diluar penelitian ini. 


\section{Saran}

Dari hasil penelitian yang telah dilakukan penulis merekomendasikan saran-saran sebagai berikut ;

1. Pimpinan dalam memacu motivasi karyawan lebih menitikberatkan pada pemberian tantangan dan penghargaan sehingga karyawan dapat melakukan pekerjaan dengan optimal guna meningkatkan kinerja.

2. Pada kemampuan kerja karyawan hendaknya prekuensi pelatihan lebih ditingkat agar wawasan dan keterampilan yang dimiliki lebih baik lagi.

\section{DAFTAR PUSTAKA}

Anwar Prabu Mangkunegara. 2009. Evaluasi Kinerja Sumber Daya Manusia. Bandung: Penerbit Refika Aditama.

Ghozali, Imam. 2005. Aplikasi Analisis Multivariate dengan Program IBM SPSS 21 Update PLS Regresi. Semarang: Badan Penerbit Universitas Diponegoro. 2013. Aplikasi Analisis Multivariate dengan Program IBM SPSS 21 Update PLS Regresi. Semarang: Badan Penerbit Universitas Diponegoro.

Giri, Ferdinan Efraim. (2005). Pengaruh Tenur Kantor Akuntan Publik (Kap) Dan Reputasi Kap Terhadap Kualitas Audit: Kasus Rotasi Wajib Auditor Di Indonesia. SNA 13 Purwokerto.

Hasibuan, Malayu. 1993. Manajemen Sumber Daya Manusia Jakarta : Bumi Aksara. 2003. Manajemen Sumber Daya Manusia Jakarta : Bumi Aksara.

Kasmir. 2015. Manajemen Sumber Daya Manusia Jakarta : PT Raja Grafindo Persada.

Mangkunegara, Anwar Prabu. 2004. Perilaku dan Budaya Organisasi. Bandung : Rafika Adi Tama Bandung.

Adi Tama Bandung.

Mathis, Robert L dan John H. Jackson, 2012. Manajemen Sumber Daya Manusia. Buku 1, Alih Bahasa: Jimmy Sadeli dan Bayu. Prawira Hie, Salemba Empat. Jakarta.

Peraturan Pemerintah Nomor 71 dan Keputusan Menteri Keuangan Nomor 184 s/d 196/KM/17/1998.

Surat Keputusan Gubernur Jawa Barat Nomor 79/BV/PEM/SK/68 tanggal 16 Maret 1968. 
Suharyadi, Purwanto. 2004. Statistika Untuk Ekonomi dan Keuangan Modern. Jakarta : Salemba Empat.

Rivai, H. Veithzal dan Sagala, Ella Jauvani. 2010. Manajemen Sumber DayaManusia Untuk Perusahaan Edisi 2. Jakarta: PT. Raja Grafindo.

Robbins, SP dan Judge. 2008. Perilaku Organisasi buku 2. Jakarta : Salemba Empat.

Wibowo . 2014 . Manajemen Kinerja . Edisi Keempat . Jakarta : Rajawali Pers. 